\title{
GAGE4 wt Allele
}

National Cancer Institute

\section{Source}

National Cancer Institute. GAGE4 wt Allele. NCI Thesaurus. Code C104485.

Human GAGE4 wild-type allele is located within Xp11.4-p11.2 and is approximately $6 \mathrm{~kb}$ in length. This allele, which encodes $\mathrm{G}$ antigen 4 protein, may play a role in tumor formation. 